\title{
Utilizing Grammarly in Teaching Writing Recount Text Through Genre Based Approach
}

\author{
Erni Yulianti ${ }^{1}$ Reni $^{2}$ \\ ${ }^{1}$ Department of English Education, Lampung University, Bandar Lampung, Indonesia \\ ${ }^{2}$ Department of Geography Education, State Yogyakarta University, Yogyakarta, Indonesia
}

Email address:

ernismansa@gmail.com (E. Yulianti),rhenie0306@gmail.com (Reni)

\section{To cite this article:}

Erni Yulianti, Reni. Utilizing Grammarly in Teaching Writing Recount Text Through Genre Based Approach. International Journal of Science, Technology and Society. Vol. 6, No. 1, 2018, pp. 1-5. doi: 10.11648/j.ijsts.20180601.11

Received: September 11, 2017; Accepted: September 28, 2017; Published: December 6, 2017

\begin{abstract}
This study investigated on utilizing Grammarly, a free online rater, in teaching writing recount text through Genre-Based Approach (GBA). This study triedto describe GBA application in the class, to know how Grammarly and GBA led to students' writing recount text, and to know students' perception in utilizing Grammarly in GBA in writing recount text. This study employed pre-experimental design one group pretest-post test (Creswell, 2008: 301). Data in this study were obtained from questionnaires and pretest-post test. Data from questionnaires, to describe the second and the third question, were analyzed by using Likert Scales and categorized into three categories: Positive, Neutral, and Negative as suggested by (Azwar, 2012: 149). Data from pretest-post test, to know the improvement of the students' writing recount text were administered by using Match T-test. The finding revealed that students had positive perception in learning writing recount text by utilizing Grammarly through genre base approach. Students understood the material explained while they were enjoying the learning process. Getting better understanding on genre-base, students felt easier to produce recount text. Pair and group discussion played an important role in writing cycles (Hyland, 2007: 136-137 and Harmer, 2007: 30) Moreover, the data showed that students had positive perception in using technology in learning writing recount text. The students thought that using word processing and Grammarly, an online rater, helped them in writing process (Gebhard, 2009: 222) Grammarly told the students' error that students were motivated to revise their works.
\end{abstract}

Keywords: Grammarly, Writing Recount Text, Genre Based Approach

\section{Introduction}

Senior high school curriculum was developed from time to time. Competence Base Curriculum known as KBK (Kurikulum Berbasis Kompetensi) was implemented from 2004 to 2006. Then, School-Base Curriculum (KTSP) implemented from 2006 to 2012. Finally, curriculum 2013 was implemented in July 2013. When curriculum was developed-considered as adaptation for recent educational paradigm-then, teacher who used the curriculum need to provide effective teaching as part of curriculum development (Richards, 2001 quoted in Aisah, 2009).

Understanding genre in writing is necessary. Harmer stated, "We can communicate successfully, especially in writing, is because we have some understanding of genre" (Harmer, 2007: 30). Teaching writing was explicitly stated in senior high school curriculum (Law of Republic of Indonesia Ministry of Education Article 22, 2006).

There were four cycles suggested in teaching writing through genre-based approach; they were "building knowledge of the field", "modeling of the text", "joint construction", and "independent construction" (Gibbons 2002: 60-61 quoted in Nisak, 2008). Teacher of English needed to know these cycles and implement those when teaching writing through genre-based approach.

Moreover, recent study found that writing skill seemed to be difficult for EFL students in language learning (Richards, 1990 quoted in Tuan, 2011) in such ways "(1) generating and organizing ideas using an appropriate choice of vocabulary, sentence and paragraph organization and (2) putting such ideas into an intelligible text" (Tuan, 2011: 1).

As Alwasilah stated on his longitudinal study "that teaching writing is focused on the theory and grammar with 
little exercise of writing and generally, the students writing are never given back to the students to be revised" (Alwasilah 2000: 108 quoted in Herawati 2009).

To minimize students' difficulties in learning writing skill for EFL students, implementing genre-based approach in teaching writing recount text gave alternative solution since genre based approach built students' knowledge, in such key points as; generic structures, appropriate linguistic choices, explicit grammar, sentence structures which enabled students to write a similar text in the next stage.

Recent studies showed that genre base approach brought benefit in teaching writing (Tuan, 2011; Yang, 2012; Nisak, 2008). Genre-based approach also enhanced students writing ability as Belcher stated, "Using the genre-based approach is its high face validity due to the fact that students are writing papers on topics that they are researching. It was helping them improve their ability to complete their written assignments successfully" (Belcher: 11).

Hyland stated, "One example of how these expectations are communicated to ESL learners is suggested by the computer program BRIDGE, used with civil engineering students at the Papua New Guinea University of technology. The program is design to assist teachers in creating useful feedback for students on their report" (Hyland, 2007: 181182).

The students write their own writing using word processingin computer that computer tells the writers' errorin such things; capitalization, punctuation, and spelling. Then, students consulted their own writing produced to Grammarly, an online rater. The use of technology here is to help the teacher and students to revise their own writing in process as Gebhard stated, "As with other language skills, computer technology has opened up new ways for teachers and students to process writing" (Gebhard, 2009: 222). This research report concerned on investigating of utilizing Grammarly in teaching writing recount text through genre based approach.

From the background of problem, the writers formulated the research questions as follow:

1. What is the effect of utilizing Grammarly toward student' writing recount text through Genre Based Approach?

2. How does Genre-based approach lead to students' perception in learning writing recount text?

3. How does technology leads to students' perception in learning writing recount text through genre-based approach.

\section{Method}

This research used pre-experimental design to know whether utilizing Grammarly in genre-based approach (independent variable) had an effect in teaching recount text (dependent variable). Theone-group pretest-posttest design was used in this study (Creswell, 2008: 301). The population of this research was the first grade of Senior High School in Pangkalpinang, Bangka Belitung Province. The first year students were chosen since writing recount text was learned by the students of the first semester of the first year based on curriculum developed at the school. Sugiyono stated, "The populationis a generalization area comprising: An object/subject that have certain qualities and characteristics that was determined by theresearchers to be learned and then drawn conclusions" (Sugiyono, 2012: 61).

There were seven classes of ten grade students. Every class contained thirty-students. Then, one group from seven classes was assigned to be the research sample. The simple random sample was assigned to obtain the sample from the population randomly. This was in line with Setiyadi statement, "There is research that toss coin to obtain one from the two parallel classes in one school, some are using the dice when there aresix parallel classes" (Setiyadi, 2006: 39).

The design of the research was as follow:

$$
\mathrm{T}_{1} \mathrm{X} \mathrm{T}_{2}
$$

$\mathrm{T}_{1}=$ pretest

$\mathrm{X}=$ treatment

$\mathrm{T}_{2}=$ posttest

The pretest was administered to know the students writing recount text ability. Then, the teacher gave the students treatments for eight times within a month and ended by giving the posttest (Hatch and Farhady, 1982: 20).

Pretest and posttest were administered. They wereessaywriting tests. The students were given a prompt. Then, they responded the prompt intorecount text essay. The students did the pretest or posttestin one hour (Tomkins, 2008: 93). The pretest was administered before the treatments. The writing cycles were administered in classroom teachinglearning activities as suggested by (Hyland, 2007: 129 and Gibbons 2002: 60-61 quoted in Nisak 2008). Next, the posttest was administered. Then, continued by administering the questionnaires. All the activities were conducted in the classroom.

To test the validity and reliability of Grammarly, then, the writerr uploaded a Recount Text taken from (Hyland, 2007; 34).

The following is the kind of Recount text. The stage of arranging the recount text consist of three stages, they are orientation, events in chronological order and re-orientation.

Furthermore, the Grammarly online rater program can detect the students' mistakes in their writing. The Grammarly has features 1] Plagiarism, 2] Contextual Spelling Check, 3] Grammar, 4] Punctuation, 5] Style and word Choice. Then, Grammarly will detect the students' text and give the information what feature is correct and incorrect; furthermore the assessing for the writing score can be seen by the students on the Grammarly program.

From the result above, it was found that Grammarly could detect the text well since the text marked 100. The program detected the text as unoriginal text because the researcher took the text from some factual genres (English K-6 syllabus, Board of studies, 1998, p.287 quoted in Hyland, 2007; 34).

And in learning Procedures in Implementing Grammarly 
in teaching writing recount text through genre-based approach.

a. Building knowledge of the topic

In this first stage, teacher built students' knowledge on the field of the meaning work in context, students' awareness of the social purpose of genres, (Hyland, 2007: 130) that later, those activities on the first stage led the students to gain enough background knowledge of the topic as a base understanding for the next steps. The activities in this stage will involve such as "speaking, listening, reading, information gathering, and note taking" (Nisak, 2008: 13).

b. Modeling text

The second stage, modeling text is a "scaffolding activity that involved teachers and learners discussing and exploring the stages of the genre and its key grammatical and rhetorical features." In this stage, the teacher gave "representative sample of the target genre" (Hyland, 2007: 132). In addition, teacher assisted the students to focus on the genre features analyzed, such as generic structures, appropriate linguistic choices, explicit grammar, sentence structures that enable students to write a similar text in the next stage.

c. Joint construction

Teacher and students constructed a target genre together as a whole-class activity. The activity led students to know the written text. The main purpose was to illustrate on the target genre writing process leads to content and linguistic choices.
The teacher "ask students to work in group to produce parallel text" while the teacher's role is as learners' facilitator. Then, teacher "gradually reducing his or her contribution as learners gains greater control over their writing" (Hyland, 2007: 136). In this stage, students utilized Grammarly as a part of scaffolding activities.

d. Independent writing

The fourth stage let the students to write a target text independently to apply what they had learned "while the teacher looks on and gives advice from the sidelines." The independent construction as the final stage on the writing cycle regard as the "core of writing instruction" and it was likely to be more productive when there was scaffolding activity such as drafting, self-editing, and discussing (Hyland, 2007: 136-137). Then, utilizing Grammarly greatly helped students in self-editing stages.

\section{Result}

\subsection{Grammarly Through Genre-Based Approach Improve Students' Writing Recount Text}

Before the t-test was used to compare the means of pretest and posttest, Kolmogorov Smirnov test was utilized to find out the normality distribution of pretest. The calculation using Kolmogorov Smirnov test was as follow

Table 1. Tests of Normality.

\begin{tabular}{lllllll}
\hline & \multicolumn{2}{l}{ Kolmogorov-Smirnov $^{\text {a }}$} & \multicolumn{3}{l}{ Shapiro-Wilk } \\
\cline { 2 - 6 } & Statistic & Df & Sig. & Statistic & Df & Sig. \\
\hline Pre test & .127 & 30 & $.200^{*}$ & .972 & 30 & .599 \\
Post test & .107 & 30 & $.200^{*}$ & .939 & .086 & 30 \\
\hline
\end{tabular}

a. Lilliefors Significance Correction

*. This is a lower bound of the true significance.

When significant (Sig.) is higher than 0.05, the distribution of pretest is normal. In contrast, when significant (Sig.) is less than 0.05 , the distribution of pretest is not normal. The data showed that the significant (Sig.) of pretest was 0.200 which was higher than 0.05 . It meant that the distribution scores of pretest were normal.

Then, to know the homogeneity of variance, the researcher administered Levene Test.

Table 2. The Levene's test and t-test between pretest and posttest.

\begin{tabular}{llllll}
\hline Group Statistics & & & & \\
\hline & Group & N & Mean & Std. Deviation & Std. Error Mean \\
\hline \multirow{2}{*}{ Pre test \& post test } & Pre test & 30 & 45.3667 & 13.73012 & 2.50676 \\
& Post test & 30 & 62.7667 & 9.48932 & 1.73250 \\
\hline
\end{tabular}

Table 3. Independent Samples Test.

\begin{tabular}{|c|c|c|c|c|c|c|c|c|c|c|}
\hline & & \multicolumn{2}{|c|}{$\begin{array}{l}\text { Levene's Test for } \\
\text { Equality of Variances }\end{array}$} & \multicolumn{7}{|c|}{ t-test for Equality of Means } \\
\hline & & \multirow[t]{2}{*}{$\mathbf{F}$} & \multirow[t]{2}{*}{ Sig. } & \multirow[t]{2}{*}{$\mathbf{T}$} & \multirow[t]{2}{*}{ df } & \multirow{2}{*}{$\begin{array}{l}\text { Sig. }(2- \\
\text { tailed) }\end{array}$} & \multirow{2}{*}{$\begin{array}{l}\text { Mean } \\
\text { Difference }\end{array}$} & \multirow{2}{*}{$\begin{array}{l}\text { Std. Error } \\
\text { Difference }\end{array}$} & \multicolumn{2}{|c|}{$\begin{array}{l}95 \% \text { Confidence Interval of } \\
\text { the Difference }\end{array}$} \\
\hline & & & & & & & & & Lower & Upper \\
\hline \multirow{2}{*}{$\begin{array}{l}\text { Pre test \& } \\
\text { post test }\end{array}$} & $\begin{array}{l}\text { Equal variances } \\
\text { assumed }\end{array}$ & 2.887 & .095 & -5.710 & 58 & .000 & -17.400 & 3.04720 & -23.499 & -11.300 \\
\hline & $\begin{array}{l}\text { Equal variances not } \\
\text { assumed }\end{array}$ & & & -5.710 & 51.55 & .000 & -17.400 & 3.04720 & -23.515 & -11.284 \\
\hline
\end{tabular}

The criterion of homogenous variance is when the probability is higher than $0.05(\mathrm{p}>0.05)$, while if the probability is less than $0.05(\mathrm{p}<0.05)$, the variance is not homogenous. The data showed that the significance value 
(Sig.) was 0.095 was higher than $0.05 \quad(\mathrm{p}>0.05)$. In conclusion, the sample of the population was homogenous.

The table provided the result from pretest and posttest. It showed that $\mathrm{t}$-count $=5.710$. The t-table with $(\mathrm{df}=\mathrm{N}-1)$, at level of significance $\alpha=0.05$ was 2.045 . The table showed that t-count was higher than t-table. Therefore, genre-based approach improved students' writing recount text.

\subsection{Genre-Based Approach Leads to Students' Perception in Learning Writing Recount Text}

Table 4. Students' perception in learning writing recount textthrough genrebased approach.

\begin{tabular}{lll}
\hline \multirow{2}{*}{ Perception Categories } & Students' Perception & \\
\cline { 2 - 3 } & Number of Respondents & Percentage \\
\hline Positive & 29 & $97 \%$ \\
Neutral & 1 & $3 \%$ \\
Negative & - & - \\
Total Respondents & 30 & $100 \%$ \\
\hline
\end{tabular}

The data showed that 29 or (97\%) students had positive perception in learning writing recount text through genrebased approach while 1 or $(3 \%)$ students' perception in learning writing recount text through genre-based was neutral.

The students understood recounted text explained by teacher (29 students) while (28 students) claimed that learning recount text through genre-based was enjoyable. Understanding genre based, the students felt easier in producing recount text (28 students). Then, scaffolding played an important role in writing cycles (27 students). Wash back was needed by students on their writing $(28$ students) to motivate them to revise their writing (29 students).

\subsection{The Use of Technology Leads to Students' Perception in Learning Writing Recount Text Through Genre-Based Approach}

The use of word processing helped students in writing process (29 students) since the program told them their error in spelling, repeated words, capitalizations, and punctuation. The students were motivated in writing recount text by the usage of Grammarly, an online rater, (27 students) since Grammarly gave wash back to students' writing (27 students) and the students believe that the wash back given by Grammarly meet its reliability (24 students).

From the interpretation above, it was found that that the students' perception was positive toward the use of technology in genre-based approach in teaching writing recount text while genre-based approach improved students writing recount text ability. Harmer stated, "We can communicate successfully, especially in writing, is because we have some understanding of genre" (Harmer, 2007: 30). It was found benefit in teaching writing using genre-based approach (Tuan, 2011; Yang, 2012; Nisak, 2008) Genrebased approach also enhanced students writing ability as Belcher stated, "Using the genre-based approach is its high face validity due to the fact that students are writing papers on topics that they are researching. It was helping them improve their ability to complete their written assignments successfully" (Belcher: 11).

\section{Discussion}

Thestudy foundthat utilizing Grammarly through genrebased approach improved students' writing recount text (Harmer, 2007) of the first grade of the first year at one of Senior High Schools in Pangkalpinang. In addition, the use of technology, Grammarly, benefited the students in writing cycles (Hyland, 2007, Brown, 2001 and Gebhard, 2009).

Therefore, these findings may be beneficial for students, educators or writing instructors text to utilize grammarly in teaching recount text through Genre Based approach and by understanding genre based, the students felt that it made them easier to produce recount text since pair and group discussion played an important role in writing cycles (Hyland, 2007: 136-137 and Harmer, 2007: 30).

Moreover, the data showed that 28 or $(93 \%)$ students had positive perception in the usage of technology in learning writing recount text. The students thought that the use of word processing and Grammarly, an online rater, helped them in writing process (Gebhard, 2009: 222). Grammarly told the students' error in writing so that the students were motivated to revise their work. In other words, they had more practices in writing (fill the absence of little exercise in writing as stated by (Alwasilah 2000: 108 quoted in Herawati 2009).

\section{Conclusion}

Based on these findings, it is recommended that genrebased approach and the usage of technology, Grammarly and word processor, be implemented in teaching writing recount text and there was needed more investigation on the usage of Grammarly, an online rater, to judge the students recount writing text compared with the writing recount text scoring rubric suggested by experts.

\section{References}

[1] Aisiah. E. E (2009). Development of English Language Teaching Syllabus in Indonesia, A Journal. Retrieved from $\mathrm{http}: / /$ englisah. wordpress.com/2009/05/11/development-ofenglish-language-teaching-syllabus-in-indonesia/

[2] Astuti. Eka M. (2006). English Zone; for Senior High School Students Year X. Erlangga.

[3] Azwar. S. (2012). Penyusunan Skala Psikologi. Pustaka pelajar.

[4] Belcher. D. Effectiveness of the Genre-based Approach for Graduate Students. Georgia State University.

[5] Brown, H. D. (2001). Teaching by Principles; An Interactive Approach to Language pedagogy. Second edition, San Francisco State university. Addison Wesley Longman, Inc. 
[6] Cresswell, John W. (2008). Educational Research, Planning, Conducting, and Evaluating Quantitative Qualitative Research. Third Edition. New Jersey: Pearson Education, Inc.

[7] Farhady, H and Evelin H. (1982). Research Design and Statistics for Applied linguistics. Los Angeles: Newbury House publishers, Inc.

[8] Gebhard. J. G. (2009). Teaching English as a Foreign or Second Language; A self-Development and Methodology Guide. The University of Michigan Press.

[9] Harmer. J. (2007). The Practice of English Language Teaching. Fourth Edition. Pearson Longman.

[10] Herawati. N. (2009). An Investigation on the Implementation of a Genre-Based Approach. (A Script, Indonesia University of Education, 2009, Unpublished).

[11] Hylan. K. (2004). Genre and Second Language Writing. Michigan Series in Teaching Multilingual Writers. The university of Michigan.

[12] Johns. M. A. (2002). Genre in the Classroom; Multiple Perceptions. Lawrence Erlbaum Associates, Publiser. Mahwah, New jersey.

[13] Law of Republic of Indonesia Ministry of Education Article 22, 2006, Standar Competence and Base Competence for Primary and Senior High School.
[14] Martine. A. S. (2002). Writing assessment released writing Prompts. Pennsylvania Department of Education Division of Evaluation and Reports.

[15] Nisak. K. (2008). The Genre basedd approach to teaching a recount Genre. (A Script, Indonesia University of Education, 2008, Unpublished).

[16] Setiyadi. B. (2006). Metode Penelitian Untuk Pengajaran Bahasa Asing; Pendekatan Kuantitatif dan Kualitatif. Graha Ilmu, Yogyakarta.

[17] Sugiyono. (2012). Statistik Untuk Penelitian. Alfabeta Bandung.

[18] Tomkins. G. E. (2008). Teaching writing; Balancing Process and Product. Fith edition, California State University Fresno America. Pearson Merrill Prentice Hall.

[19] Tuan. L. T. (2011). Teaching Writing through Genre-Based Approach. Theory and Practice in Language Studies, Vol. 1, No. II, pp. 147-1478, November 2011 C 2011 ACADEMY PUBLISHER Manufactured in Finland. Doi: 10.4304/tpls.1.11.1471-1478.

[20] Yang. W. (2012). A study of Students' Perceptions and Attitudes towards Genre-Based ESP Writing Instruction. Asian ESP Journal. National Kaohsiung University of Hospitality and Tourism, Taiwan. Volume 8 Issue 3 Autumn 2012. 